\title{
Understanding Autoimmune Diseases- A Review
}

\author{
Dr.Deepak Viswanath ${ }^{1}$ \\ 1(Professor, Department of Pedodontics and Preventive Dentistry, Krishnadevaraya College of Dental Sciences \\ and Hospital, India)
}

\begin{abstract}
Autoimmune disorder is an umbrella term for a variety of painful conditions involving a malfunction in the body's complex immune system. In a normal immune response to an infection or invasion, the immune system causes a temporary inflammation while it kills off the invader cells. In autoimmune disorders, this inflammation becomes chronic, causing pain and permanent changes or damages the involved tissues. There is no specific cause for autoimmune disorders; they show patterns of remission and recurrence and they are difficult to diagnose because the specific disorders have different possible symptoms and individual symptoms varies. This article introduces a number of autoimmune diseases and inflammatory myopathies. It includes a definition of autoimmune diseases as well as a short explanation of immunity.
\end{abstract}

Key words: autoimmune disease, autoimmunity, immune disease, immune tolerance, reactive arthritis

\section{Introduction}

The immune system specifically recognises and eliminates foreign agents thereby protecting the host against infection. During maturation of the immune system, immune cells that react against self-tissues are eliminated providing an immune system that is 'tolerant' to self. More recently, researchers have realised that autoimmunity is a natural phenomenon, with self-reactive antibodies and autoimmune cells present in all individuals. A combination of genetic predisposition and environmental factors contribute to the development of autoimmune disease. Because many autoimmune diseases start at a relatively young age and continue throughout life, they have a disproportionate effect on public health; furthermore, most autoimmune diseases are chronic in nature requiring a lifetime of care. Understanding the mechanisms that lead to dysregulation of the immune response resulting in autoimmune disease is necessary to develop better therapies to treat and possibly even prevent these diseases.

\section{A Brief Over-View Of Immune System}

One definition of the immune system is that it is an intricate set of cellular, chemical and soluble protein mechanisms, intended to shield the body against alien substances such as infections and tumor cells, without attacking self-molecules. The distinction between self-molecules and alien substances occurs through intricate mechanisms that are dependent on certain recognition molecules present on the surface of immune competent cells, specifically, T and B lymphocytes. A small percentage of T and B lymphocytes form a normal part of the immune cell pool. Tolerance is preserved by the controlled interactions of various cell types and soluble mediators; however, in certain environments, tolerance can be broken resulting in an autoimmune pathogen.

- Autoimmunity is defined as the development of immune system reactivity in the form of auto-antibodies and T-cell responses to self-structures. There are many known autoimmune diseases ranging from tissue specific disorders to systemic disorders.

- The definition of autoimmune disease: This definition includes a variety of diseases which can be described by the irregular functioning of the immune system that causes an individual's immune system to generate antibodies which attack their own body tissues.

- Immune tolerance is defined as specific non-reactivity of the immune system to a particular antigen, which is capable under other circumstances of inducing an immune response.

Most immune system cells are white blood cells; lymphocytes are of one type. There are several types of lymphocytes in the adaptive immune system; each has a specific job to perform. T-cells help identify and eliminate antigens, and B-cells produce antibodies that each attach to one special antigen and mark it for destruction by other immune system cells.

T-cells are critical immune system cells that help to destroy infected cells and coordinate overall immune response. There are three types of T-cells:

- Helper T-cells, which signal B-cells to produce stronger antibodies

- Cell-killing (cytotoxic) T-cells which produce molecules that destroy cells carrying antigens

- Suppressor T-cells which dampen other immune responses. 
The T-cell has a molecule on its surface called the T-cell receptor. This receptor interacts with MHC (major histocompatibility complex). MHC molecules are on the surfaces of most other cells of the body and help Tcells recognise antigen fragments. Cells that signal the T-cells are called antigen-presenting cells (APCs).

\section{The role of APC (antigen-presenting cells)}

APCs fall into two categories: professional and non-professional

2.1.1 Professional APCs: are very efficient at internalizing antigens, either by phagocytosis or by receptormediated endocytosis, and then displaying a section of the antigen, bound to a class II MHC molecule, on their membrane. The T-cell recognises and interacts with the antigen class II MHC molecule complex on the membrane of the antigen-presenting cell. An additional costimulatory signal is then produced by the antigenpresenting cell, leading to activation of the T-cell. The expression of costimulatory molecules is a defining feature of professional APCs. There are three main types of professional APCs; Dendritic cells, which have the widest range of antigen presentation, and are probably the most important APCs; Macrophages and B-cells, which express and secrete specific antibody and can internalise the antigen.

2.1.2 Non-professional APCs: a non-professional APC does not constitutively express the MHC class II proteins required for interaction with naïve T-cells; these are only expressed once the non-professional APCs are stimulated by certain cytokines such as IFN- $\gamma$. Non-professional APCs include fibroblasts (skin), thymic epithelial cells, thyroid epithelial cells, glial cells (brain), pancreatic beta cells and vascular endothelial cells. ${ }^{1}$

Other key players in autoimmune disease are messenger molecules called cytokines and chemokines. Cytokines are proteins that can activate immune cells and affect nonimmune processes and thereby cause inflammation and damage. Chemokines are small molecules that attract other immune cells and can contribute to the invasion and inflammation of the target organ. For example, overproduction of chemokines in the joints of people with rheumatoid arthritis may result in invasion of the joint space by destructive immune system cells such as macrophages, neutrophils and T-cells.

\section{Classification of Autoimmune Diseases}

For clinicians, autoimmune diseases appear to be either systemic (e.g. systemic lupus erythematosus) or organ-specific (e.g. Type 1 diabetes mellitus). This classification, although clinically useful, does not necessarily correspond to a difference in causation. A more useful division distinguishes between diseases in which there is a general alteration in the selection, regulation or death of T cells or B cells and those in which an aberrant response to a particular antigen, self or foreign, causes autoimmunity. An example of a general defect is the absence of the Fas protein or its receptor- proteins involved in cell death- and a representative antigen specific disorder is the demyelination syndrome that follows enteric infection Campylobacterjejuni. This classification is useful in deciding on therapy, which may differ according to the pathogenic mechanism.

Alterations that lower the threshold for the survival and activation of autoreactive B cells often cause the production of multiple autoantibodies, as in the case of the antinuclear and anti-DNA antibodies in systemic lupus erythematosus. ${ }^{2-6}$ Low levels of these autoantibodies are the rule in all people. Genetic alterations with global effects on the function of regulatory $\mathrm{T}$ cells or cytokine production often leads to inflammatory bowel disease. ${ }^{7,8}$ This process may reflect enhanced activation of $\mathrm{T}$ cells with an exuberant response to gut flora.

\section{Genetic Risk Factors}

The development of autoimmune diseases depends on a combination of genetic and environmental factors. Most autoimmune diseases are thought to be polygenic, involving more than one gene. There is familial clustering, and the rate of concordance for autoimmune disease is higher in monozygotic twins than in dizygotic twins. ${ }^{9-11}$ A few autoimmune diseases, such as autoimmune lymphoproliferative syndrome and the syndrome of autoimmune polyglandular endocrinopathy with candidiasis and ectodermal dysplasia (APECED), are due to mutations in single gene. Even in these conditions, other genes modify the severity of disease and not all who possess the mutant gene manifest the disease.

Most autoimmune diseases are multigenic, with multiple susceptibility genes working in concert to produce the abnormal phenotype. In general, the polymorphisms also occur in normal people and are compatible with normal immune function. Only when present with other susceptibility genes do they contribute to autoimmunity. ${ }^{12,13}$ Some of these genes confer a much higher level of risk than others; for e.g. the major histocompatibility complex makes an important contribution to disease susceptibility. Most autoimmune diseases are linked to a particular class I or II HLA molecule,${ }^{14}$ but this association may require linkage with another gene such as that encoding tumor necrosis factor $\alpha(\mathrm{TNF}-\alpha)$ or complement.

Human lymphocyte antigen or HLA haplotype, is the best available predictor of developing an autoimmune disease. The likelihood of developing similar autoantibodies relates directly to sharing HLA haplotypes with family members and the probability is even greater if two haplotypes rather than one are shared. Thus, heredity 
accounts for about one-third of the risk of developing an autoimmune disease, while noninherited, environmental factors account for the remaining $70 \%$ risk.

\section{Environmental Factors}

Environmental factors may have various roles in promoting, causing or modifying autoimmune diseases. If, and when specific environmental factors contribute to autoimmune diseases, they may well determine the onset of illness, the nature of initial manifestations, or be a determining factor on whether an autoimmune disease contained within an individual might occur at all. ${ }^{15}$

Environmental factors are one of the most important initiators determining the time and type of autoimmune disease when one is manifested. The type of disease in an individual, in an autoimmune prone family, can be determined by a specific combination of various infectious agents, chemicals, drugs and vaccines.

1.1 Hormones- Most autoimmune diseases are more prevalent in women than men; conservative estimates indicate that nearly $80 \%$ of individuals with autoimmune diseases are women. Exceptions include diabetes mellitus, ankylosing spondylitis and inflammatory heart disease. Hormones are obtained from external sources like diet (soy), drugs (birth control pills) or skin products in addition to production of steroids by the body. Sex hormones directly interact with cells of the immune system via receptors on the surface; and steroid hormones are known to influence antibody production and immune cell proliferation. Thus, hormones can amplify or inhibit the immune response.

1.2 Toxic metal exposure- A predicted $25 \%$ of individuals have some form of heavy metal poisoning. Studies have shown that exposure to toxic metals such as mercury, cadmium, lead, arsenic, aluminium and nickel can be linked to autoimmune process resulting in autoimmune diseases.

1.3 Toxic chemical exposure- Toxins such as pesticides, industrial chemicals, some household cleaners and hair dyes can be linked to autoimmune diseases.

1.4 Diet- Inflammation can be triggered by an inadequate diet, which is deficient in nutrients but exceeds in toxins. In many conditions like Alzheimer's, epilepsy, migraine, fibromyalgia and chronic fatigue, there is a deficiency of magnesium; which can trigger autoimmune diseases. Magnesium supplements are used to stop epilepsy attacks.

1.5 Vaccinations/ Immunizations- Scientists have found a connection between some autoimmune diseases and certain vaccinations; for e.g., the contentious anthrax vaccine has been causally linked to the development of certain autoimmune diseases.

1.6 Infections- Several mechanisms have been proposed for how infections can lead to autoimmune disease including direct viral damage, release of cryptic self-peptides, antigenic spread, molecular mimicry, bystander activation and the adjuvant effect. Molecular mimicry is the concept that antigens of the microorganism closely resembles self-antigens and when an infection occurs, autoimmunity is induced. Bystander activation may occur when the immune response is non-specifically stimulated by the infection resulting in activation of autoimmunity in genetically susceptible individuals. The adjuvant effectdescribes the specific activation of the innate immune response by microbial antigens as occurs, for e.g., during administration of adjuvants in vaccines. A number of autoimmune diseases can be induced experimentally by administering self-antigen with adjuvant, such as rheumatoid arthritis with collagen and myocarditis with cardiac myosin.

1.7 Smoking and autoimmune diseases- Tobacco smoking is one of the most powerful factors that could prompt autoimmune diseases. Smoking has been associated with systemic lupus erythematosus (SLE); the prevalence rate, ratios for current and past smoking for the development of the disease has been found to be 1.6. The prevalence of smoking with rheumatoid arthritis is even more established. Smoking interacts genetic risk factors such as HLA-DR alleles, making up to an estimated 21-fold risk of disease. Smoking can contribute to autoimmunity by various mechanisms; it causes tissue damage and increases apoptosis through production of free radicals, release of metalloproteinase, and the induction of Fas expression on lymphocytes. Smoking also provokes inflammation as it causes an increase in fibrinogen levels, induces leucocytosis, and elevated C-reactive protein, intercellular adhesion molecule-I and E-selectin.

\section{Antibody-Mediated Damage}

Antibodies or immunoglobulins are a family of glycoproteins present in the serum and tissue fluids of all mammals. Antibodies can be carried on the surface of B-cells, acting as receptors, or free in the blood and lymph. Specific binding of antigens causes B-cells to produce large amounts of antigen-specific antibody. These antibodies provide critical protection against infectious microorganisms immediately following infection and are the key protective immune response induced by vaccination. Similarly, self-reactive or autoantibodies are important in clearing cellular debris induced by inflammation or physical damage to the body. 
A common feature of all autoimmune diseases is the presence of autoantibodies, which are an important factor in the diagnosis or classification of autoimmune diseases. Due to the chronic nature of most autoimmune diseases, autoantibodies appear long before clinical symptoms; in fact, the risk of developing an autoimmune disease rises from about $10 \%$ if one autoantibody is present to around $60-80 \%$ if three autoantibodies are present for a particular autoimmune disease.

Autoantibodies can induce damage to the body by binding to self-tissues, activating the complement cascade and inducing lysis. This occurs in certain forms of haemolytic anemia when autoantibodies bind to red blood cell surface antigens inducing lysis of red blood cells.

\section{Cell-Mediated Damage}

Damage induced by cells of the immune system play a major pathogenic role in many autoimmune diseases. The predominant infiltrating cells include phagocytic macrophages, neutrophils, self-reactive CD4+ T helper cells and self-reactive CD8+ cytolytic cells, with smaller number of natural killer cells, mast cells and dendritic cells. Immune cells damage tissues directly by killing cells or indirectly by releasing cytotoxic cytokines, prostaglandins, reactive nitrogen or oxygen intermediates.

Tissue macrophages and monocytes can act as antigen-presenting cells to initiate an autoimmune response, or as effector cells once an immune response has been initiated. Macrophages and neutrophils damage tissues by releasing highly cytotoxic proteins like nitric oxide and hydrogen peroxide. Cytokines and other mediators released by macrophages recruit other inflammatory cells, like neutrophils and T-cells, to the site of inflammation.

\section{Tolerance}

Mechanisms of self-tolerance, defined as a state of nonresponsiveness to self, can be divided into central and peripheral tolerance. In central tolerance, immature lymphocytes in the bone marrow (B-cells) and thymus (Tcells) that recognise self-antigens with high affinity die by apoptosis or programmed cell-death. In peripheral tolerance, mature self-reactive lymphocytes are inactivated, killed or turned off by regulatory mechanisms including functional anergy, ignorance and suppression by regulatory T-cells. Defects in tolerance leading to autoimmune disease may occur in one or multiple tolerance mechanisms. For e.g. changes in the apoptotic cell death or survival or disturbances in clearing apoptotic cells, are thought to be involved in the pathogenesis of a number of autoimmune diseases such as rheumatoid arthritis, lupus and Hashimoto's thyroiditis.

\section{Risks For Developing Autoimmune Diseases}

Table 1 gives examples of autoimmune disorders and risks for developing these disorders depending on the family history

\section{Profiles Of Autoimmune Diseases}

Table 2 gives various types of autoimmune diseases and their symptoms

\section{Future therapeutic approaches for treating autoimmune diseases}

Four general approaches to therapy are being explored (Table 3): altering thresholds of immune activation, modulating antigen-specific responses, reconstituting the immune system with autologous or allogenic stem cells, and sparing of target organs.

Interference with costimulation, signalling, chemokines and other molecules critical to immune activation is designed to restore homeostasis in the immune system and dampen the autoimmune response. It is based on the concept that small changes in the availability of proteins that control interactions between cells or participate in intracellular signalling can divert the immune system away from autoreactivity.

Antigen-specific therapies aim to induce tolerance to a particular antigen. Exposure of the immune system to autoantigens or appropriate peptides delivered either by ingestion to induce oral tolerance ${ }^{20}$ or by ingestion ${ }^{31}$ has worked well in animals but not in humans. ${ }^{32}$ Perhaps, this approach can only work during the initial activation of autoreactive cells, because once disease is clinically apparent, the immunologic milieu may be inflammatory and epitope spreading may have occurred. An approach involving stem-cell transplantation has engendered much excitement recently and pilot studies of reconstitution with autologous and allogenic stem cells are proceeding in patients with systemic lupus erythematosus, rheumatoid arthritis, scleroderma and multiple sclerosis $^{26,33-35}$ with a hope to restore homeostasis with regulatory cells.

\section{Conclusion}

The complex causes of autoimmune diseases not only present a challenge to the development and testing of new therapies but also offer a framework that allows the identification of subgroups of patients who might benefit from particular approaches. Although we will encounter both successes and setbacks, continued studies of 
autoimmune diseases in humans and animals are necessary to help identify the most appropriate strategies for each disease.

\section{References}

[1]. Ercolini A, Miller S.D. The role of infections in autoimmune disease. J Trans Immunol 2009 (available on http://www.ncbi.nlm.nih.gov/pmc/articles/PMC2665673. Accessed 25 August 2011)

[2]. Dang H, Geiser AG, Letterio JJ, et al. SLE-like autoantibodies and Sjogren's syndrome-like lymphoproliferation in TGF-beta knockout mice. J Immunol 1995; 155: 3205-12

[3]. Konotoyiannis D, Kollias G. Accelerated autoimmunity and lupus nephritis in NZB mice with an engineered heterozygous deficiency in tumor necrosis factor. Eur JImmunol 2000; 30: 2038-47

[4]. Napirei M, Karsunky H, Zevnik B, Stephan H, Mannherz HG, Moroy T. Features of systemic lupus erythematosus in Dnase1deficient mice. Nat Genet 2000; 25: 177-81

[5]. Botto M. C1q knock-out mice for the study of complement deficiency in autoimmune disease. Exp Clin Immunogenet 1998; 15: 231-4

[6]. Nishimura H, Nose M, Hiai H, Minato N, Honjo T. Development of lupus-like autoimmune diseases by disruption of the PD-1 gene encoding an ITIM motif-carrying immunoreceptor. Immunity 1999; 11: 141-51

[7]. Bhan AK, Mizoguchi E, Smith RN, Mizoguchi A. Colitis in transgenic and knockout animals as models of human inflammatory bowel disease. Immunol Rev 1999; 169: 195-207

[8]. Blumberg RS, Saubermann LJ, Strober W. Animal models of mucosal inflammation and their relation to human inflammatory bowel disease. Curr Opin Immunol 2000; 12: 226

[9]. Ortonne JP. Recent developments in the understanding of pathogenesis of psoriasis. Br J Dermatol 1999; 140: Suppl 54: 1-7

[10]. Kukreja A, Maclaren NK. Autoimmunity and diabetes. J Clin Endocrinol Metab 1999; 84: 4371-8

[11]. Gregersen PK. Genetic analysis of rheumatic diseases. In: Kelley WN, Harris ED Jr, Ruddy S, Sledge CN, eds. Textbook of rheumatology. $5^{\text {th }}$ ed. Vol. 1. Philadelphia: W.B. Saunders, 1997: 209-27

[12]. Encinas JA, Kuchroo VK. Mapping and identification of autoimmunity genes. CurrOpin Immunol 2000; 12: 691-7

[13]. Becker KG. Comparative genetics of type I diabetes and autoimmune disease: common loci, common pathways? Diabetes 1999; 48: $1353-8$

[14]. Klein J, Sato A. The HLA system. N Engl J Med 2000; 343: 782-6

[15]. Alarcon-Riquelme M, Alarcon-Segovia D. Shared Autoimmunity: The concept and introduction. Autoimmunity 2005; 38(3): 199

[16]. Abrams JR, Lebwohl MG, Guzzo CA, et al. CTLA4Ig-mediated blockade of T-cell costimulation in patients with psoriasis vulgaris. J Clin Invest 1999; 103: 1243-52

[17]. Dinarello CA. The role of the interleukin-1-receptor antagonist in blocking inflammation mediated by interleukin-1. $N$ Engl $J$ Med 2000; 343: 810-1

[18]. Asadullah K, Docke WD, Sabat RV, Volk HD, Sterry W. The treatment of psoriasis with IL-10: rationale and review of the first clinical trials. Expert Opin Investig Drugs 2000; 9: 95-102

[19]. Denham W, Fink G, Yang K, Ulrich P, Tracey K, Norman J. Small molecule inhibition of tumor necrosis factor gene processing during acute pancreatitis prevents cytokine cascade progression and attenuates pancreatitis severity. Am Surg 1997; 63: 1045-50

[20]. Weiner HL. Oral tolerance for the treatment of autoimmune diseases. Anпи Rev Med 1997; 48: 341-51

[21]. Bielekova B, Goodwin B, Richert N, et al. Encephalitogenic potential of the myelin base protein peptide (amino acids 83-99) in multiple sclerosis: results of a phase II clinical trial with an altered peptide ligand. Nat Med 2000; 6: 1167-75

[22]. Falk K, Rotzschke O, Santambrogio L, Dorf ME, Brosnan C, Strominger JL. Induction and suppression of an autoimmune disease by oligomerized T-cell epitopes: enhanced in vivo potency of Encephalitogenic peptides. J Exp Med 2000; 191: 717-30

[23]. Matsumoto Y, Jee Y, Sugisaki M. Successful TCR-based immunotherapy for autoimmune myocarditis with DNA vaccines after rapid identification of pathogenic TCR. J Immunol 2000; 164: 2248-54

[24]. Wallace DJ. Clinical and pharmacological experience with LJP-394. Expert OpinInvestig Drugs 2001; 10: 111-7

[25]. Neuhas O, Farina C, Yassouridis A, et al. Multiple sclerosis: comparison of copolymer-1-reactive T-cell lines from treated and untreated subjects reveals cytokine shift from T helper 1 to T helper 2 cells. Proc Natl Acad Sci U S A 2000; 97: 7452-7

[26]. Marmont AM. New horizons in the treatment of autoimmune diseases: immunoablation and stem cell transplantation. Annu Rev Med 2000; 51: 115-34

[27]. Mizuno M, Nishikawa K, Morgan BP, Matsuo S. Comparison of the suppressive effects of soluble CR1 and CR5a receptor antagonist in acute arthritis induced in rats by blocking of CD59. Clin Exp Immunol 2000; 119: 368-75

[28]. Papadakis KA, Targan SR. The role of chemokines and chemokine receptors in mucosal inflammation. Inflamm Bowel Dis 2000; 6: 303-13

[29]. Brown PD. Ongoing trials with metalloproteinase inhibitors. Expert Opin InvestigDrugs 2000; 9: 2166-77

[30]. Paul-Clark MJ, Gilroy DW, Willis D, Willoughby DA, Tomlinson A. Nitric oxide synthase inhibitors have opposite effects on acute inflammation depending on their route of administration. J Immunol 2001; 166: 1169-77

[31]. Ramiya VK, Shang XZ, Wasserfall CH, Maclaren NK. Effect of oral and intravenous insulin and glutamic acid decarboxylase in NOD mice. Autoimmunity 1997; 26: 139-51

[32]. Weiner HL, Mackin GA, Matsui M, et al. Double-blind pilot trial of oral tolerization with myelin antigens in multiple sclerosis. Science 1993; 259: 1321-4

[33]. Burt RK, Traynor A, Burns W. Hematopoietic stem cell transplantation of multiple sclerosis, rheumatoid arthritis, and systemic lupus erythematosus. Cancer Treat Res 1999; 101: 157-84

[34]. Comi G, Kappos L, Clanet M, et al. Guidelines for autologous blood and marrow stem cell transplantation in multiple sclerosis: a consensus report written on behalf of the European Group for Blood and Marrow Transplantation and the European Charcot Foundation. J Neurol 2000; 247: 376-82

[35]. Nash R.A. Prospects of stem cell transplantation in autoimmune diseases. J ClinImmunol 2000; 20: 38-45 
Table 1: Risks for developing autoimmune disorders

\begin{tabular}{|c|c|}
\hline $\begin{array}{l}\text { AUTOIMMUNE } \\
\text { DISEASES }\end{array}$ & RISKS \\
\hline Behcet's disease & Upto $10 \%$ risk for first degree relatives \\
\hline Crohn disease & $\begin{array}{l}10-20 \% \text { of cases appear to run in families; risk for first degree } \\
\text { relatives }\end{array}$ \\
\hline Dermatitis herpetiformis & $\begin{array}{l}\text { Autosomal dominant, } 50 \% \text { recurrence risk and females are more } \\
\text { affected than males }\end{array}$ \\
\hline Grave's disease & $\begin{array}{l}\text { Clusters in families with other autoimmune disorders; } \\
\text { recurrence risks are not specified }\end{array}$ \\
\hline Hashimoto's thyroiditis & $\begin{array}{l}\text { Clusters in families with other autoimmune disorders; } \\
\text { recurrence risks are not specified }\end{array}$ \\
\hline Multiple sclerosis & $\begin{array}{l}3-5 \% \text { for first degree relatives; } 38 \% \text { for monozygotic twins; } \\
30 \% \text { for offspring of two affected parents; } 0.5-3 \% \text { for brothers } \\
\text { of an affected sibling; } 1.5-8 \% \text { for sisters of an affected sibling }\end{array}$ \\
\hline Myasthenia gravis & $\begin{array}{l}\text { Genetically heterogeneous; usually occurs by chance. } 1-4 \% \text { of } \\
\text { cases cluster in a family; and familial predisposition may be due } \\
\text { to autoimmunity in general; occurs both as dominant and } \\
\text { recessive form }\end{array}$ \\
\hline Pemphigus vulgaris & Autosomal dominant; 50\% recurrence risk \\
\hline Pernicious anemia & $\begin{array}{l}20 \% \text { of relatives with pernicious anemia, have pernicious } \\
\text { anemia, especially first-degree female relatives; recurrence risks } \\
\text { not specified }\end{array}$ \\
\hline $\begin{array}{l}\text { Polymyositis/ } \\
\text { Dermatomyositis }\end{array}$ & $\begin{array}{l}\text { Clusters in families with other autoimmune disorders; } \\
\text { recurrence risks not specified }\end{array}$ \\
\hline Psoriasis & $\begin{array}{l}\text { One-third of cases appear to run in families; seen more in } \\
\text { Caucasians and in women. Lifetime risk if one parent has } \\
\text { psoriasis }=0.28 \text {; if both parents }=0.65 \text {; if one parent and one } \\
\text { affected child }=0.51 \text { and if both parents and one affected } \\
\text { child }=0.83\end{array}$ \\
\hline Rheumatoid arthritis & $\begin{array}{l}\text { Females are } 2-3 \text { times more likely to be affected than males; risk } \\
\text { for parents and siblings of an affected individual is about } 2 \\
4.5 \%\end{array}$ \\
\hline Scleroderma & $1 \%$ recurrence risk for first degree relatives \\
\hline Sjogren's syndrome & $\begin{array}{l}9 / 10 \text { patients are females; } 50 \% \text { of cases occur alone while } 50 \% \\
\text { of cases occur in the presence of another autoimmune disease }\end{array}$ \\
\hline $\begin{array}{l}\text { Systemic } \\
\text { erythematosus }\end{array}$ & $\begin{array}{l}\text { 9/10 patients are females; first degree relatives have a } 8-9 \text { fold } \\
\text { increased risk over the general population }\end{array}$ \\
\hline $\begin{array}{l}\text { Type I or immune mediated } \\
\text { diabetes mellitus }\end{array}$ & Recurrence risk is $4 \%$; up to $50 \%$ if multiple affected relatives \\
\hline
\end{tabular}

Table 2: Types of autoimmune diseases and their symptoms

\begin{tabular}{|l|ll|}
\hline \multicolumn{1}{|c|}{ Disease } & \multicolumn{1}{c|}{ Symptoms } \\
\hline $\begin{array}{l}\text { Alopecia areata: the immune system attacks hair } \\
\text { follicles }\end{array}$ & - & Patchy hair loss on the scalp, face \\
\hline $\begin{array}{l}\text { Antiphospholipid antibody syndrome: a disease that } \\
\text { causes problems in the inner lining of blood vessels } \\
\text { resulting in blood clots or veins }\end{array}$ & - $\begin{array}{l}\text { Blood clots in veins or arteries } \\
\text { - }\end{array}$ \\
\hline $\begin{array}{l}\text { Autoimmune hepatitis: the immune cells attack and } \\
\text { destroys the liver cells which can cause scarring and } \\
\text { eventually liver failure }\end{array}$ & and knees \\
& - & Fatike red rash on wrists \\
& - Itchy skin \\
\hline $\begin{array}{l}\text { Celiac disease: a disease in which people can't } \\
\text { tolerate gluten, a substance found in wheat, rye and } \\
\text { barley; and if people consume gluten, the immune }\end{array}$ & - Stomach pain/ upset \\
\hline
\end{tabular}




\begin{tabular}{|c|c|}
\hline system damages the lining of small intestines. & $\begin{array}{ll}\text { - } & \text { Itchy skin } \\
\text { - } & \text { Fatigue }\end{array}$ \\
\hline $\begin{array}{l}\text { Diabetes type I: a disease in which the immune } \\
\text { system attacks the cells that make insulin leading to a } \\
\text { chain of events. }\end{array}$ & $\begin{array}{ll}\text { - } & \text { Being very thirsty } \\
\text { - } & \text { Polyuria } \\
\text { - } & \text { Feeling very hungry or tired } \\
\text { - } & \text { Losing weight without trying } \\
\text { - } & \text { Dry itchy skin } \\
\text { - } & \text { Having blurry eyesight }\end{array}$ \\
\hline $\begin{array}{l}\text { Grave's disease (overactive thyroid): a disease } \\
\text { where there is increased amount of thyroid hormone }\end{array}$ & $\begin{array}{ll}\text { - } & \text { Insomnia and irritability } \\
\text { - } & \text { Muscle weakness and heat } \\
& \text { sensitivity } \\
\text { - } & \text { Bulging eyes } \\
\text { - } & \text { Fine brittle hair } \\
\text { - } & \text { Sometimes there are no symptoms }\end{array}$ \\
\hline $\begin{array}{l}\text { Guillain-Barre syndrome: the immune system } \\
\text { attacks the nerves connecting brain and spinal cord } \\
\text { with the rest of the body. }\end{array}$ & $\begin{array}{l}\text { - Weakness or tingling feeling in } \\
\text { the feet } \\
\text { - } \quad \text { Paralysis, in extreme cases }\end{array}$ \\
\hline Hashimoto's disease (underactive thyroid) & $\begin{array}{ll}\text { - } & \text { Weakness and fatigue } \\
\text { - } & \text { Facial swelling and weight gain } \\
\text { - } & \text { Muscle aches and stiff joints } \\
\text { - } & \text { Constipation }\end{array}$ \\
\hline $\begin{array}{l}\text { Inflammatory myopathies: a group of diseases } \\
\text { involving muscle inflammation and muscle } \\
\text { weakness; are of } 2 \text { types, polymyositis and } \\
\text { dermatomyositis }\end{array}$ & $\begin{array}{l}\text { - Slow but progressive muscle } \\
\text { weakness beginning around the } \\
\text { trunk region. } \\
\text { - } \quad \text { Fatigue after standing/ walking } \\
\text { - } \quad \text { Tripping or falling } \\
\text { - } \quad \text { Difficulty in swallowing or eating }\end{array}$ \\
\hline $\begin{array}{l}\text { Multiple sclerosis (MS): a disease where the } \\
\text { immune system attacks the protective coating around } \\
\text { the nerves. }\end{array}$ & 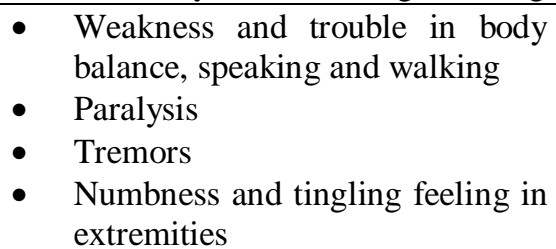 \\
\hline $\begin{array}{l}\text { Myasthenia gravis (MG): a disease where the } \\
\text { immune system attacks the nerves and muscles } \\
\text { throughout the body }\end{array}$ & $\begin{array}{l}\text { - A Double vision and droopy } \\
\text { eyelids } \\
\text { - Difficulty in swallowing, with } \\
\text { frequent gagging or choking } \\
\text { - Weakness or paralysis } \\
\text { - Drooping head } \\
\text { - Difficulty in climbing stairs, } \\
\text { lifting things and talking }\end{array}$ \\
\hline $\begin{array}{l}\text { Psoriasis: a disease where new skin cells that grow } \\
\text { deep in the skin rises too fast and piles on the surface }\end{array}$ & $\begin{array}{l}\text { - Thick red patches, covered with } \\
\text { scales, appear on head, elbows } \\
\text { and knees } \\
\text { - Itching and pain } \\
\text { - A form of arthritis affecting the } \\
\text { joints and ends of fingers and } \\
\text { toes }\end{array}$ \\
\hline $\begin{array}{l}\text { Rheumatoid arthritis: a disease where the immune } \\
\text { system attacks the lining of the joints throughout the } \\
\text { body }\end{array}$ & $\begin{array}{l}\text { - } \begin{array}{l}\text { Painful, stiff, swollen and } \\
\text { deformed joints }\end{array} \\
\text { - } \text { Reduced movement and function } \\
\text { - } \quad \text { Fever, fatigue, weight loss, eye } \\
\text { inflammation, anaemia may also } \\
\text { be seen }\end{array}$ \\
\hline $\begin{array}{l}\text { Sjogren's syndrome: a disease where the immune } \\
\text { system targets the glands that make moisture such as } \\
\text { saliva and tears }\end{array}$ & $\begin{array}{ll}- & \text { Dry eyes or itchy eyes } \\
\text { - } & \text { Dryness of mouth, which leads to } \\
\text { sores }\end{array}$ \\
\hline
\end{tabular}




\begin{tabular}{|c|c|}
\hline & $\begin{array}{ll}\text { - } & \text { Rampant dental caries } \\
\text { - } & \text { Loss of taste sensation } \\
\text { - } & \text { Joint swelling or pain } \\
\text { - } & \text { Swollen glands }\end{array}$ \\
\hline $\begin{array}{l}\text { Systemic lupus erythematosus: a disease that } \\
\text { damages the joints, skin, kidneys, heart, lungs and } \\
\text { other parts of the body. Also called SLE or lupus }\end{array}$ & $\begin{array}{ll}\text { - } & \text { Fever and fatigue } \\
\text { - } & \text { Weight loss } \\
\text { - } & \text { Hair loss } \\
\text {-butterfly" rash across nose and } \\
\text { - } \\
\text { - } \text { Rasheeks on other parts of body } \\
\text { - } & \text { Senst pain } \\
\text { - } & \text { Headaches, dizziness, seizures, or } \\
& \text { change in behavior }\end{array}$ \\
\hline $\begin{array}{l}\text { Vitiligo: the immune system destroys the cells that } \\
\text { give the skin its color }\end{array}$ & $\begin{array}{l}\text { - White patches on areas exposed } \\
\text { to sun, or on armpits, genitals and } \\
\text { rectum } \\
\text { - } \quad \text { Hair turns grey early } \\
\text { - } \quad \text { Loss of color in the mouth }\end{array}$ \\
\hline $\begin{array}{l}\text { Haemolytic anemia: The immune system destroys } \\
\text { the red blood cells. }\end{array}$ & $\begin{array}{ll}\text { - } & \text { Fatigue } \\
\text { - } & \text { Shortness of breath } \\
\text { - } & \text { Dizziness and headache } \\
\text { - } & \text { Cold hands or feet } \\
\text { - } & \text { Paleness and yellowish skin } \\
\text { - } & \text { Heart problems, including heart } \\
& \text { failure }\end{array}$ \\
\hline $\begin{array}{l}\text { Idiopathic thrombocytopenic purpura: A disease in } \\
\text { which the immune system destroys blood platelets. }\end{array}$ & 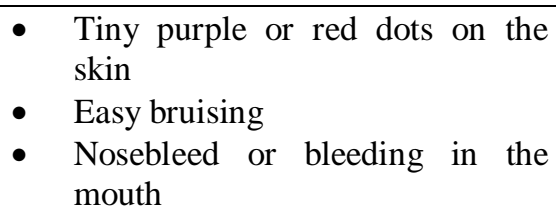 \\
\hline
\end{tabular}

Table 3: Therapeutic approaches

Alteration of thresholds of immune system

- Blockade of costimulatory factors ${ }^{16}$

- Antagonism of inflammatory cytokines ${ }^{17}$ or protective cytokines ${ }^{18}$

- Inhibition of signalling cascades by small molecules ${ }^{19}$

Modulation of antigen-specific cells

- Induction of regulatory cells (intravenous, subcutaneous or oral delivery of antigen) $)^{20}$

- Alteration in peptide ligands ${ }^{21}$

- Formation of complexes of peptide and major-histocompatibility complex molecules ${ }^{22}$

- Development of T-cell receptor vaccines ${ }^{23}$

- Induction of B-cell tolerance ${ }^{24}$

- Immune deviation from type I to type II helper T-cells ${ }^{25}$

Reconstitution of the immune system ${ }^{26}$

- Bone marrow ablation with autologous stem cells

- Bone marrow ablation with donor stem cells

- Bone marrow ablation without stem cells

Sparing of target organs

- Antagonism of complement ${ }^{27}$

- Antagonism of chemokines ${ }^{28}$

- Use of anti-inflammatory agents

- Inhibition of matrix metalloproteases ${ }^{29}$

- Inhibition of nitric oxide synthase ${ }^{30}$ 